\title{
Research on Implementation of University Computer Foundation Teaching Reform
}

\author{
Xinfeng Yang \\ School of Computer and Information Engineering, Nanyang Institute of Technology, Nanyang, \\ China \\ ywind2005@163.com
}

Keywords: University computer foundation teaching; Teaching reform; Implementation

\begin{abstract}
With the development of social informationization, the computer level has become a measure of the professional quality and ability of college students. This paper analysis the present situation and defects of current teaching of university computer foundation, puts forward the goal and thought of reform, from the reform of teaching concept, teaching content reform, teaching method reform and the way of examination reform in four aspects elaborated the specific content of the reform.
\end{abstract}

\section{Introduction}

With the development of social informationization, the information process of all walks of life is accelerating [1-3]. Employers of college graduates of computer capacity requirements also increased, computer level has become the measure of a prominent sign of the quality and ability of professional college students, and for the independent colleges, computer basic education performance out teaching management and implementation aspects of immaturity, to make computer basic education to adapt to the needs of the social development, and effectively improve the college students' computer application level and operation ability, it need us to proceed from reality, analysis teaching reality, strive to innovation, further reform and improve the university computer foundation teaching[4-5].

\section{The Current Situation and Disadvantages of Teaching}

Education Level is not Clear, Teaching Lack Humanization. In recent years, our country accelerate the process of information technology education in primary and secondary schools, more than $80 \%$ of the students in the middle school stage learned basic information courses, on the other hand the computer ownership rate for now enrolled in the University family is high, close to half of the students have a computer application ability [6]. But as a result of computer basic education in the small school belongs to the minor subjects, computer level cannot be regarded as a basis of examination and enrollment, which are caused to the status of large difference in college freshmen level of basic computer [7]. According to some colleges and universities survey data show, $8 \%$ has reached university first computer class enrollment; $39 \%$ learned some, but not up to the standard of accounted; it did not come into contact with computer also accounted for a certain proportion, this situation brings great difficulties to the organization of teaching in Colleges and universities[8-9]. If teaching starting point is too low, will make the degree of good students affected, if the starting point is too high, the teaching only serve for a small number of top students, which will seriously hurt the most students enthusiasm for learning, results poor students more and more poor, the overall teaching quality is difficult to guarantee[10].

Exam Oriented Psychology of Students is Serious, Knowledge and Skills Development is not Enough. Through the computer grade examination is uniform requirements for university computer foundation, which makes teacher have the quantitative criteria and control scales for teaching, but because the question types and questions of computer grade examination are relatively fixed, prompting student's opportunistic psychological exam is very serious, only to grade examination test content learning interest, does not take an examination of almost ignored, even 
some students already through the grade examination by gulping or rote learning when they did not complete computer basic course or computer basic course is not open. Thus lead computer based teaching tends to the situation of single study target, narrow range of teaching, and fixed teaching content; students only know one without knowing the other, learning enthusiasm is not improved, and expand knowledge ability is poor, this brought very disadvantageous influence to the basic computer teaching.

Students Emphasis on Internet Entertainment, Lack of Computer Applications. For college students, computer network should be an important beneficial tool used to arm themselves, and according to the investigation results of many universities, college students use Internet mainly for the chat accounted for $34 \%$, mainly for gamers accounted for $28 \%$, mainly for check the information accounted for $30 \%$ and other accounted for $8 \%$, so it seems, $62 \%$ of the college students addicted to online entertainment, and engaged in activities unrelated to work and learning online. The reason caused this situation has a great relationship with the defects of school opened the computer basic course, curriculum content is too theoretical, lack skills training of the practical application, and out of thousands of scenes of the network, make the students lack of fresh sense of learning computer foundation. Therefore, the university computer foundation teaching needs to innovate.

\section{The Reform Target and Thinking}

In "Opinions on Further Strengthening the basic teaching of computer in Colleges and Universities" issued by the computer teaching guidance committee of Ministry of Education, the computer basic course is located in: the ultimate goal of curriculum reform is to establish public course which content is more stable, standardized, systematic and advanced, similar to college mathematics and English. The aim of computer basic teaching is strive to improve students' computer application ability, application of computer knowledge and technology is good at solving the practical problems of the professional based on learning computer basic knowledge and basic principles. Starting from this purpose, we put forward a comprehensive reform and practice of computer basic course teaching, and put forward the goal, plan and main measures for the construction of computer basic teaching.

The construction target of computer basic curriculum is: construct computer basic curriculum into foundation courses which train non-computer science students basic computer knowledge and computer skills, adapt to the discipline integration, reasonable knowledge structure.

According to the construction target of computer basic teaching, combined with the development and application of computer technology, the basic idea of the basic teaching construction is: according to the demand of social development. Analysis the computer knowledge people must master, establish the knowledge structure of computer application, find the general knowledge modules to construct basic computer teaching content; according to the continuous development of the computer, constantly update the teaching contents, research advanced teaching concept, actively explore innovative practice, cultivate students' innovation ability in computer application. According to the development of modern teaching management requirements, improve the way of the examination and assessment; use the advanced paperless examination mode on local area network.

\section{The Specific Content of the Reform}

Reform of Teaching Idea. Teaching idea runs through the whole teaching activities, it will not only affect our teaching way, methods and teaching effects, but also have a great impact on students' learning process and even thinking mode. In order to do better in the basic computer courses teaching, based on teaching research and practice, we proposed teaching idea of fine theory and Important practice, use the curriculum scheme of "1 + X", "1 + X" program that one "University Computer Foundation" + some required / Elective courses. 
Fine theory is that based on students understanding the basic concepts, add the latest and cutting-edge field knowledge of the development of computer science, and stimulate students' interest to pay attention to the development of computer science, gradually do the initiative, spontaneous learning and absorbing useful knowledge. Colleges and universities focus on creation of the "University Computer Foundation".

Important practice mainly trains students' computer operation skills. While master the theory, strengthen the manipulative ability, actually operate a computer, master basic office, design, multimedia, animation and other software application, to enable students to solve the various problems encountered in the study and work.

Reform of Teaching Content. Universities and colleges are characterized by distinct characteristics; the teaching content of computer basic courses should be closely combined with the professional knowledge and the actual industry, so that the computer knowledge and professional knowledge complement each other. Computer knowledge and professional knowledge should not be two separate individuals; computer knowledge is an important cornerstone of professional knowledge learning. Computer basic teaching should be treated as a professional distinction; teaching content should be as close as possible to the students' professional knowledge and industry practice. This is not only for the help in faster better grasp the basic knowledge and basic application of computer, to improve the students' subjective initiative, but also help students to understand and grasp the professional knowledge in the field of computer application, to further enhance the professional quality, professional development awareness.

Reform of Teaching Methods. (1).The Realization of Modular Teaching. Make computer basic knowledge, operation skill, theory and knowledge of technology modularization, product the operating skills into the template of instance, through the examples to explain and demonstrate the concrete operation process, highlighting operation at the same time, strengthen basic technology and theory explain, that is consistently fine theory and practice of teaching philosophy, for students to further improve operation skills, understand new computer technology to lay a good foundation.

(2).Ways of Teaching in Different Levels. The resources and environment of the current teaching need to be improved. The class and exercises in computer room cannot meet the requirements of modern teaching. Students need hierarchical, rich and detailed teaching resources. A variety of ways to contact the students in class, such as email, phone, QQ, for the first time in answering the students encountered in learning and computer related problems. Share teaching resources, including notes, the multimedia courseware outside and experimental guide books, material library, BBS problem discussion area rich teaching resources and software. Each of them is into system and interrelated, from easy to difficult, from simple to complex, guide the students to gradually increase, each one takes what he needs.

(3).Use flexible and advanced teaching methods, carry out a variety of teaching activities, and effectively improve the students' computer literacy. The computer knowledge and ability training in largely depends on the students hands-on practice and study, basic computer teachers should put the teaching emphasis placed in the student problem analysis and problem solving ability and the innovation spirit training, guide students in an introductory, should be good at using the flexible advanced teaching idea and teaching method, as it is now advocated by the heuristic method of teaching, application and project driven teaching method, task driven teaching method, to enable students to from passive recipients of knowledge transferred to do the masters of learning up. Such as teaching excel, lets the student on their balance of payments this week to do a statistical, and set the question in a number of key operations, which greatly caused the students' interest in learning, to encourage students to take the initiative to understand and grasp the excel table text input editing and formula calculation, operation skills and the students' daily living expenses understand the situation and education they how to live and study. To improve the study of computer basic knowledge and application skills, by classroom teaching is not enough, often held computer basic knowledge and operating skills contest, can greatly stimulate students learning computer hobbies, exercise students' autonomous learning ability, and cultivate students' computer literacy. 
(4).Actively dredge and guide. Some people think: "college student is populations which received good education and produces a great impact on the future of the country, if their network quality can't keep up with development of the times, then the country also very difficult become powerful in the future of the digital economy. " Thus, educate and guide college students to correctly use the network have become an important measure to promote social progress. How to avoid students addicted to online entertainment, in addition to the society and family education, basic computer education workers should regard as own duty, with a rich and interesting computer knowledge effectively clear guide, transfer students focus to how to use the Internet to improve their own personality and their professional development, realize active learning.

Reform of Examination Methods. Examination is an important link in the teaching process of higher education. It is an important measure to stabilize the teaching order and guarantee the quality of teaching. It is also an important means to evaluate the gains and losses of teaching and the feedback of teaching work. The traditional course exam often is about teaching, teacher proposition, roll out the examination, teachers marking, human factors is more. For public basic courses, because many teachers, many students, if we use the traditional examination methods, the results obtained will reduce the objectivity due to the limitation of the scope of item difficulty and test paper examines. For computer basic course examination, our main reform is the separation of teaching and examination, no paper examination.

The ability is put in the first place in the examination, such as the "University Computer Foundation" courses including computer literacy and basic computer skills training. the operation of the computer can be as the main content, such as text word processing, spreadsheet processing excel, PowerPoint presentations to handle PowerPoint, the basic computer skills is divided into different modules in the form of computer test, realize the examination process of paperless and field operation.

Examination methods are as follows:

(1).Strengthens process assessment. Each stage of the teaching process requires students to submit their work according to the requirements.

(2).Participate in the final exam of the course; this test uses a computer pumping test template

\section{Summary}

In a word, the reform and innovation of college computer basic teaching need to actively play the guiding role of the teacher, the enthusiasm of inspiring students learning computer, mobilize the initiative in learning, and comprehensively improve their basic quality of computer, lay a solid foundation for the future study and work.

\section{Acknowledgement}

The author is grateful to the support of research project of general education curriculum teaching reform of Nanyang Institute of Technology.

\section{References}

[1] G.L. Chen, R.S. Dong. China University Teaching, (2011) No.1, p.12.

[2] K. Li. China University Teaching, (2012) No.1, p.45.

[3] Q.M. He, H.Q. Li, B.Q. Feng. China University Teaching, (2010) No.9, p.35.

[4] Z.Y. Li. China University Teaching, (2014) No.6, p.9.

[5] Spady. Educational Leadership, Vol. 51 (1994) No.6, p.18.

[6] X. Hu. Software Guide, (2013) No.1, p.171.

[7] Y.L. Gao. China Education Innovation Heral, (2009) No.26, p.34. 
[8] C9. China University Teaching, (2010) No.9, p.97.

[9] B.Q. Feng. China University Teaching, (2012) No.9, p.15.

[10]M. He, W.W. Chen, X.L. Chen, X.G. Ye, F. Yang, K. Wang. Computer Engineering \& Science. Vol. 36 (2014) No.A1, p.96. 